\title{
RELEVÂNCIA JURÍDICA DOS ENCADEAMENTOS DECISÓRIOS E OUTROS PROCESSOS TRANSFRONTEIRIÇOS: O EXEMPLO DE SEU IMPACTO SOBRE BARREIRAS COMERCIAIS BRASILEIRAS NA "GUERRA DOS PNEUS"
}

\author{
Marcus Faro de Castro ${ }^{1}$ \\ Hugo Pena ${ }^{2}$
}

\begin{abstract}
Resumo
Análises jurídicas convencionais de políticas públicas locais são comumente feitas mediante abordagens formalistas do ordenamento doméstico. Este artigo propõe que tais abordagens apresentam "pontos cegos", limitações analíticas quanto aos processos de determinação e estrutura de normas jurídicas correlatas à formulação de políticas públicas. O estudo toma como exemplo a análise de uma política comercial de restrição a importações de pneus automotivos, aplicada no Brasil desde a década de 1990. Os conflitos que se desenrolaram a partir da aplicação desta política, que ficaram conhecidos como "guerra dos pneus", exemplificam a relevância de encadeamentos decisórios que envolvem interações e tensões entre espaços domésticos e transfronteiriços. $\mathrm{O}$ trabalho argumenta que encadeamentos como estes podem ser incorporados ao discurso jurídico por diferentes expedientes intelectuais. Dentre as diversas possibilidades, o artigo aborda aspectos da noção de "freios e contrapesos parcialmente internacionalizados", do referencial das ordenações jurídicas transnacionais e da categoria de deflexão monetária interportfolio. A relevância dos encadeamentos decisórios transfronteiriços também motiva a discussão sobre o expressivo papel de indicadores globais na determinação normativa, a caracterizar outro ponto cego nas abordagens jurídicas convencionais sobre a formulação de políticas locais.
\end{abstract}

Palavras-chave: Freios e contrapesos. Direito e relações internacionais. Ordenações jurídicas transnacionais. Comércio internacional. Guerra dos pneus.

\section{INTRODUÇÃO}

Na década de 1990, o Poder Executivo brasileiro iniciou uma política de proibição de importação de pneus usados. Tal política, contudo, gerou controvérsias locais. Liminares e decisões da Justiça Federal, em diversos pontos do país, autorizaram importações de pneus em casos concretos. Na década de 2000, o Mercosul adentrou o "jogo de forças" pela definição da política aplicável ao comércio de pneus. O Mercosul introduziu uma exceção à proibição de importação de pneus remoldados, favorecendo, assim os países do bloco. A norma proveniente do Mercosul foi subsequentemente contestada com sucesso na OMC pelas Comunidades

\footnotetext{
${ }^{1}$ Doutor em Direito pela Universidade de Harvard. Professor titular da Faculdade de Direito da Universidade de Brasília (UnB). Email:mfarounb@gmail.com

${ }^{2}$ Doutorando em Direito (UnB). Bolsista de doutorado da CAPES. E-mail: hlpfhugo@yahoo.com
} 
Europeias. Como resultado, o Brasil deveria eliminar o caráter discriminatório de sua política, que foi percebida pela OMC como consistindo em uma "fachada" de motivações sanitárias e ambientais levantadas para restringir a entrada de pneus usados, por trás da qual se desenrolavam práticas seletivas de importação, autorizadas judicialmente ou dirigidas ao favorecimento de países específicos.

Apesar de abordagens jurídicas convencionais desenvolverem referenciais para gerar uma representação intelectual da estruturação de políticas públicas como aquela envolvida no exemplo acima, elementos concretamente relevantes tendem a ser deixados de fora das análises produzidas. O viés formalista do olhar jurídico (cf. CASTRO, 2012) implica, nesse sentido, a existência de "pontos cegos" a respeito da gênese e transformação das próprias instituições jurídicas. Tais pontos cegos se revertem em falhas no emprego de referenciais jurídicos como balizadores de políticas públicas. Em outros termos, o fechamento do olhar jurídico a elementos empiricamente pertinentes à dinâmica institucional guarda relação com a perda de sua relevância para a proposição de reformas consequentes (CASTRO, 2012).

Uma das limitações do discurso jurídico convencional é a sua incapacidade de lidar adequadamente com a existência de encadeamentos decisórios transfronteiriços que compõem, na prática, o jogo pela definição do comportamento estatal. A "guerra dos pneus" evidencia que a definição de políticas públicas nacionais tem engastes em elementos das relações internacionais que extrapolam doutrinas mais comumente disponíveis para o discurso jurídico convencional, tal como a chamada doutrina dos "freios e contrapesos" ${ }^{3}$. Tais encadeamentos sugerem a inadequação da percepção que vincula o formato assumido por políticas públicas exclusivamente aos desdobramentos relativos ao ordenamento jurídico nacional, porque este é permeado pela influência de atores para além dos que são corriqueiramente representados como os poderes Legislativo, Executivo e Judiciário, com autoridade territorialmente delimitada.

Outro "ponto cego" do discurso jurídico convencional diz respeito à relevância que a articulação do conhecimento na forma de indicadores tem para o comportamento estatal. Na realidade, os indicadores têm sido empregados como guias para a elaboração de políticas públicas, bem como ferramentas para sua avaliação, nas mais variadas áreas e temas ${ }^{4}$. Em outros termos, indicadores têm implicações normativas. Tais implicações normativas atravessam os limites territoriais dos Estados e influenciam o jogo de encadeamentos decisórios transfronteiriços.

\footnotetext{
${ }^{3}$ Vejam-se, como exemplos de obras que aplicam análises baseadas nessa doutrina: Novelino, 2009, p. 342-3; Motta; Barchet, 2009, p. 86, Abramovay, 2012. Nos dois primeiros exemplos, as doutrinas de John Locke (separação de poderes) e Montesquieu (freios e contrapesos) aparecem de modo embaralhado, como se fossem complementares ou convergentes, ao passo que Abramovay (2012) distingue as duas formulações, identificando elementos que as tornam divergentes.

${ }^{4}$ Este é o foco da obra Governance by indicators: global power through quantification and rankings., de Davis et al(2012). Alguns aspectos de suas contribuições são levantados, a seguir, na seção 4.
} 
Embora convencionalmente o jurista possa descartar encadeamentos decisórios e outros processos transfronteiriços como elementos mais afeitos ao olhar do cientista político, do economista, do estatístico, ou do estudioso das relações internacionais, o fechamento do olhar jurídico para tais elementos revela-se inadequado diante da percepção de que estes têm, no plano prático da realidade, participação nos processos que levam à estruturação de políticas públicas, da política econômica, e das instituições jurídicas que thes são correlatas. Nesse sentido, a marginalização desses elementos pelo olhar jurídico acaba contribuindo para a perda de relevância técnica e política do trabalho jurídico para a orientação dos processos envolvidos na gênese das próprias instituições jurídicas. $O$ direito perde espaço, assim, para esferas de saber que se mostram menos dogmaticamente fechadas a lidar com elementos empiricamente relevantes.

O presente artigo tem o objetivo de destacar a importância que encadeamentos decisórios e outros processos transfronteiriços têm sobre a dinâmica das instituições jurídicas. A seção 2 focaliza a guerra dos pneus como evidência prática de uma dinâmica transnacional de configuração de uma política pública brasileira. Em seguida, a seção 3 apresenta algumas possibilidades para representar encadeamentos decisórios transfronteiriços. São elas: a noção de freios e contrapesos parcialmente internacionalizados (3.1) e a teoria das ordenaçôes jurídicas transnacionais (3.2). A seção 4, por sua vez, aborda outros processos transfronteiriços com relevância normativa, como a deflexão monetária interportfólio (4.1) e a influência de indicadores globais sobre o comportamento estatal e a dinâmica institucional (4.2). Considerações finais são feitas na seção $5 .^{5}$

\section{GUERRA DOS PNEUS E SEUS ENCADEAMENTOS DECISÓRIOS TRANSFRONTEIRIÇOS}

Em 1991, o governo de Fernando Collor iniciou uma política de proibição à importação de bens de consumo usados no Brasil, juridicamente formalizada por meio de portaria do Departamento de Comércio Exterior (DECEX), então ligado ao Ministério da Fazenda ${ }^{6}$. A proibição afetou a importação de pneus usados. Nos anos seguintes, outras normas (vide Quadro 2, abaixo) editadas por setores do Poder Executivo complementaram a proibição e explicitaram seu alcance em relação aos pneus.

Entre os interesses afetados pelas medidas do Poder Executivo estavam os de empresas brasileiras do ramo de reforma de pneus. Diversas ações foram propostas na Justiça Federal, em pontos variados do país, objetivando a obtenção de autorizações judiciais para a importação. Ao menos 24 empresas tiveram sucesso nas demandas judiciais, inclusive pela obtenção de medidas liminares. Juridicamente, sustentavam que a proibição de importação do insumo à sua produção seria incompatível com o princípio constitucional da livre iniciativa

\footnotetext{
${ }^{5}$ Ao longo do texto, trechos citados de obras em idiomas estrangeiros foram traduzidos livremente pelos autores.

${ }^{6}$ Trata-se da Portaria 8, de 14 de maio de 1991, do DECEX/Ministério da Fazenda. 
(OLIVEIRA, 2012, p. 124). A criação de tais "brechas" judiciais à política restritiva iniciada pelo Executivo foi, porém, apenas a primeira etapa da chamada "guerra dos pneus" 7 .

A segunda etapa envolveu a interpretação da portaria já mencionada (vide Quadro 1 - distinções terminológicas). A categoria de pneus "reformados" (com o sentido de recauchutados, recapados ou remoldados) não se encontrava expressamente abrangida no texto da Portaria 9/1991 do DECEX. Na prática, a ausência da menção expressa aos pneus "reformados" na proibição de importação encorajou os comerciantes a manter a importação de tais pneus por não serem eles classificados como "usados", e isto apesar de o respectivo processo de industrialização - destinado ao reuso em veículos - ter o pneu usado como matéria-prima. Em 2000, a Secretaria de Comércio Exterior (SECEX) brasileira - sucessora do Departamento de Comércio Exterior - alterou as normas para vedar, agora de modo expresso, a concessão de licenças de importação a pneus usados e reformados (SOUZA, 2010, p. 29).

\section{Quadro 1 - Pneus: distinções terminológicas}

\begin{tabular}{|c|c|c|c|c|}
\hline \multicolumn{5}{|c|}{ Pneus } \\
\hline \multirow{4}{*}{ Novos } & \multicolumn{4}{|c|}{ Usados $^{8}$} \\
\hline & \multirow{2}{*}{ Inservíveis } & \multicolumn{3}{|c|}{ Reformados } \\
\hline & & Recapados & Recauchutados & Remoldados \\
\hline & $\begin{array}{l}\text { Resíduos; } \\
\text { insusceptíveis de } \\
\text { reforma. }\end{array}$ & $\begin{array}{l}\text { Passam por } \\
\text { substituição da } \\
\text { "banda de } \\
\text { rodagem" }\end{array}$ & $\begin{array}{l}\text { Passam por substituição da } \\
\text { "banda de rodagem" e de } \\
\text { parte das "paredes laterais". }\end{array}$ & $\begin{array}{l}\text { Passam por substituição da } \\
\text { "banda de rodagem", das } \\
\text { "paredes laterais" e "ombros } \\
\text { da carcaça". }\end{array}$ \\
\hline
\end{tabular}

Fonte: elaborado a partir de dados colhidos em OLIVEIRA, 2012, p. 115, 118; SOUZA, 2008, p. 29; MOTTA, 2008

A medida adotada pela SECEX contrariou mais uma vez interesses de grupos de comerciantes. Empresas uruguaias que exportavam remoldados ao Brasil mobilizaram-se junto ao governo uruguaio para questionar a compatibilidade da proibição brasileira em relação às normas do Mercosul. Na perspectiva do Executivo brasileiro, a portaria da SECEX havia meramente esclarecido a interpretação de norma proibitiva já

\footnotetext{
${ }^{7}$ Produções acadêmicas brasileiras abordaram a chamada "guerra dos pneus" com diferentes enfoques, como se pode observar pelos exemplos a seguir. A abordagem feita em Sanchez et al. (2007) é centrada na participação (inédita) que entidades da sociedade civil tiveram, na qualidade de amici curiae, no contencioso junto à OMC. O texto faz, ainda, panorama dos argumentos empregados pelas Comunidades Europeias e pelo Brasil na disputa. Souza (2010) analisa o contencioso na OMC e a decisão do STF na ADPF 101, considerando a participação do judiciário como "fonte doméstica" da política externa brasileira. O trabalho realiza uma projeção da categoria de judicialização da política inicialmente abordada em Castro (1997), e utiliza aspectos da guerra dos pneus como expressões da judicialização da política externa brasileira. Já em Oliveira (2012), o tema central é a sobreposição de jurisdições capazes de decidir sobre comércio internacional verificada na guerra dos pneus. Sua abordagem compreende panorama das normas brasileiras, dos litígios no judiciário nos momentos iniciais da política, dos contenciosos no Mercosul e na OMC e da discussão no STF, permitindo uma compreensão global da disputa.

${ }^{8}$ Segundo Motta (2008), 46,8\% dos pneus usados no Brasil voltam a rodar após passar ou não por reforma. Os demais 53,2\% chegam ao final de sua vida útil e passam a ser classificados como "inservíveis". Ainda segundo a autora, o "processo de reforma dos vol.09, n. 04, Rio de Janeiro, 2016. pp. 1982-2006 1985
} 
existente: remoldados seriam espécie do gênero de pneus usados. Porém, na perspectiva que passou a ser a do governo do Uruguai, tratava-se de nova restrição ao comércio entre os países do Mercosul.

Em demanda contra o Brasil no Tribunal Arbitral ad hoc do Mercosul, o Uruguai teve ganho de causa (OLIVEIRA, 2012, p. 120)9 . Consequentemente, em atendimento à decisão do tribunal arbitral, o Poder Executivo brasileiro editou nova portaria, abrindo exceção à importação de pneus reformados provenientes de membros do Mercosul.

Essa "segunda etapa" já representa a influência prática exercida por um espaço transfronteiriço de decisão sobre o formato da política brasileira de restrição à importação de pneus usados. $\mathrm{O}$ adensamento do aspecto "transnacional" da disputa se daria com o envolvimento da Organização Mundial do Comércio (OMC). Na perspectiva das Comunidades Europeias, a política brasileira aplicável aos pneus remoldados configurava prática discriminatória de comércio internacional. A regulamentação formal sobre a matéria adotada no Brasil seria apenas, segundo o bloco europeu, uma "fachada" que, embora ventilasse embasamentos ambientais e sanitários, estaria a encobrir a importação seletiva de grandes quantidades de pneus usados, por força de decisões do Poder Judiciário, e de remoldados, como resultado da "exceção Mercosul". A demanda europeia foi então levada ao mecanismo de solução de controvérsias da OMC, configurando uma "terceira etapa" da guerra dos pneus ${ }^{10}$.

Nesse ponto, ocorre um desdobramento paralelo relevante. Após o início da demanda na OMC (mas antes do relatório do Painel), o Poder Executivo brasileiro provocou a manifestação do Supremo Tribunal Federal (STF) por meio da propositura de uma Ação de Descumprimento de Preceito Fundamental (ADPF) 101 (Brasil, 2009). A pretensão jurídica da Presidência da República era obter declaração do tribunal máximo brasileiro de que as normas que vedavam importações de pneus usados e remoldados eram constitucionais. Com isso, a Presidência da República pretendia derrubar as decisões judiciais em sentido contrário. A inicial da ADPF também requeria a declaração de constitucionalidade da "exceção Mercosul".

pneus pode ser repetido uma única vez para pneus de automóveis de passeio, e até três vezes para caminhões de carga." (MOTTA, 2008, p. 173)

${ }^{9}$ Em junho de 2000, os Estados Partes do Mercosul haviam estabelecido, por meio do artigo primeiro da decisão 22/00 do Conselho do Mercado Comum, a proibição de adoção de medidas restritivas ao comércio intrabloco. Em 2002, os árbitros do tribunal ad hoc do Mercosul decidiram unanimemente que a portaria n. 8 da SECEX, de setembro de 2000, introduzia novas restrições ao comércio no Mercosul. Dada a incompatibilidade com as normas do bloco, os árbitros decidiram que o Brasil deveria adaptar sua legislação interna para permitir a importação de pneus remoldados, dando ganho de causa ao Uruguai (MERCOSUR, 2002, p. 44-5)

${ }^{10}$ A disputa envolvendo a política brasileira de restrição às importações de pneus usados na OMC - DS322 Brazil: measures affecting imports of retreaded tires - abrangeu dois momentos decisórios, que foram os relatórios do Painel (WTO, 2007a) e do Órgão de Apelação (WTO, 2007b). O Painel considerou que o volume expressivo de pneus importados via liminares judiciais, frente à proibição de importação, resultava em restrição disfarçada ao comércio internacional e tratamento discriminatório. Em termos gerais, decidiu que a política brasileira era conflitante com as normas do GATT, embora não tenha condenado, especificamente, a exceção conferida pelo Brasil ao comércio de remoldados oriundos do Mercosul (2007a). As Comunidades Europeias apelaram do relatório do Painel, questionando aspectos da fundamentação empregada no relatório e a conclusão a respeito da exceção ao Mercosul. Apesar de ter mantido diversos aspectos dos fundamentos do relatório do Painel, o Órgão de vol.09, nº. 04, Rio de Janeiro, 2016. pp. 1982-2006 1986 
No STF, a disputa foi versada em termos do choque entre os princípios constitucionais da livre iniciativa, de um lado, e de proteção à saúde e ao ambiente, de outro ${ }^{11}$. Por oito votos a um, o plenário deu ganho de causa à Presidência da República, favorecendo os princípios por ela defendidos. A procedência do pedido foi, contudo, "parcial", porque não abrangeu, ao contrário do que pretendeu o Executivo, as decisões já transitadas em julgado (BRASIL, 2009).

Quadro 2 - Cronologia de normas e decisões envolvidos na "guerra dos pneus"

\begin{tabular}{|c|c|c|c|}
\hline Ano & $\begin{array}{l}\text { Norma / } \\
\text { Decisão }\end{array}$ & $\begin{array}{l}\text { Espaço } \\
\text { decisório }\end{array}$ & Conteúdo \\
\hline 1991 & Portaria 8 & $\begin{array}{l}\text { DECEX- } \\
\text { MF }\end{array}$ & (14. maio 1991) Proibiu importação de bens de consumo usados \\
\hline 1992 & $\begin{array}{l}\text { Decisões } \\
\text { judiciais }\end{array}$ & $\begin{array}{l}\text { Justiça } \\
\text { Federal }\end{array}$ & $\begin{array}{l}\text { Juízes federais deram início à prática de autorizar (inclusive por meio de } \\
\text { decisões liminares), caso a caso, a importação de pneus usados. }\end{array}$ \\
\hline 1996 & Resolução 23 & CONAMA & Definiu pneus usados como "resíduos inertes" de importação proibida. \\
\hline 1999 & $\begin{array}{l}\text { Resolução } \\
258\end{array}$ & CONAMA & $\begin{array}{c}\text { Tornou produtores e importadores responsáveis pela "destinação } \\
\text { ambientalmente adequada" dos pneus inservíveis }\end{array}$ \\
\hline 2000 & Decisão 22 & $\begin{array}{l}\text { CMC / } \\
\text { Mercosul }\end{array}$ & $\begin{array}{l}\text { (29 jun. 2000). Proibiu a introdução de novas medidas restritivas ao } \\
\text { comércio entre membros do Mercosul. }\end{array}$ \\
\hline 2000 & Portaria 8 & $\begin{array}{l}\text { SECEX- } \\
\text { MDIC }\end{array}$ & (25 set. 2000). Proibiu a importação de pneus usados e remoldados \\
\hline 2001 & Decreto 3919 & $\begin{array}{l}\text { Pres. da } \\
\text { República }\end{array}$ & $\begin{array}{c}\text { Estabeleceu multa de } \mathrm{R} \$ 400,00 \text { por pneu importado usado ou } \\
\text { reformado encontrado no país, tornando a importação uma infração } \\
\text { administrativa. }\end{array}$ \\
\hline 2001 & - & Mercosul & $\begin{array}{c}\text { (set. 2001) Uruguai solicitou instauração de procedimentos arbitrais no } \\
\text { Mercosul contra o Brasil (Prohibición de Importación de Neumáticos } \\
\text { Remoldeados Procedentes de Uruguay) }\end{array}$ \\
\hline 2002 & $\begin{array}{l}\text { Tribunal } \\
\text { Arbitral ad } \\
\quad \text { hoc }\end{array}$ & Mercosul & $\begin{array}{l}\text { (9 jan. 2002) Laudo arbitral considerou restrições brasileiras à } \\
\text { importação de remoldados provenientes do Mercosul uma "nova } \\
\text { restrição comercial", vedada pelas regras do bloco, e que o Brasil deveria } \\
\text { adequar sua legislação interna para eliminar a barreira. }\end{array}$ \\
\hline 2002 & Portaria 2 & $\begin{array}{l}\text { SECEX- } \\
\text { MDIC }\end{array}$ & $\begin{array}{l}\text { (8 mar. 2002). Abriu exceção permissiva à importação de pneus } \\
\text { remoldados provenientes do Mercosul }\end{array}$ \\
\hline 2003 & Decreto 4592 & $\begin{array}{l}\text { Pres. da } \\
\text { República }\end{array}$ & Isentou de multa os pneus remoldados importados do Mercosul. \\
\hline 2005 & - & OSC/OMC & $\begin{array}{c}\text { Comunidades Europeias solicitaram consultas junto ao Brasil na OMC } \\
\text { (Caso DS332 - Brasil - Medidas que afetam a importação de pneus } \\
\text { recauchutados) }\end{array}$ \\
\hline 2006 & - & STF & (21 set. 2006) Propositura da ADPF 101 pela Presidência da República, \\
\hline
\end{tabular}

Apelação considerou que a exceção ao Mercosul configurava discriminação injusta ao comércio internacional, ainda que proveniente de decisão arbitral do Tribunal ad hoc do Mercosul. Reverteu, portanto, este aspecto da decisão (2007b).

${ }^{11}$ Esse aspecto é evidenciado pelo seguinte parágrafo do voto da relatora, Ministra Carmen Lúcia: "E não se pretenda seja essa questão simples, pois, de um lado, empresas defendem o direito - que, segundo elas, seria o da liberdade de iniciativa - de se utilizarem daquele resíduo para os seus desempenhos, do que advém, inclusive emprego para muitas pessoas, e, de outro, há os princípios constitucionais fundamentais da proteção à saúde e da defesa do meio ambiente saudável em respeito até mesmo às gerações futuras." (BRASIL, 2009, p. 88) 


\begin{tabular}{|c|c|c|c|}
\hline & & & $\begin{array}{c}\text { representada pela AGU, requerendo declaração da constitucionalidade } \\
\text { das normas emitidas pelo Executivo (inclusive das que dizem respeito } \\
\text { ao Mercosul) e declaração de inconstitucionalidade das interpretações e } \\
\text { decisões judiciais em sentido contrário. }\end{array}$ \\
\hline 2007 & $\begin{array}{c}\text { Relatório do } \\
\text { Painel }\end{array}$ & OSC/OMC & $\begin{array}{l}\text { (12 jun. 2007). Entendeu que as barreiras brasileiras configuravam } \\
\text { prática discriminatória de comércio internacional incompatível com as } \\
\text { regras do GATT (em virtude da grande quantidade de pneus que } \\
\text { ingressavam via liminares judiciais, mas não em virtude da exceção } \\
\text { aberta aos remoldados do Mercosul), e deveriam ser modificadas. }\end{array}$ \\
\hline 2007 & $\begin{array}{l}\text { Relatório do } \\
\text { Órgão de } \\
\text { Apelação }\end{array}$ & OSC/OMC & $\begin{array}{c}\text { (3 dez. 2007). Após apelação das Comunidades Europeias, o } \\
\text { OAp/OMC entendeu que a exceção brasileira aos remoldados do } \\
\text { Mercosul era inconsistente com as normas do GATT e deveria ser } \\
\text { extinta. }\end{array}$ \\
\hline 2009 & APDF 101 & STF & $\begin{array}{l}\text { (11 mar. - } 24 \text { jun. 2009) Plenário do STF declara constitucionais as } \\
\text { normas restritivas à importação de pneus e derruba decisões judiciais } \\
\text { em sentido contrário, à exceção das transitadas em julgado. A “exceção } \\
\text { Mercosul” foi ponto obscuro no desfecho do julgamento. }\end{array}$ \\
\hline 2009 & Parecer & AGU & $\begin{array}{l}\text { (6 ago. 2009) Entendeu que o voto da Ministra Carmen Lúcia declarou } \\
\text { a inconstitucionalidade da "exceção Mercosul". }\end{array}$ \\
\hline 2009 & Portaria 24 & $\begin{array}{l}\text { SECEX - } \\
\text { MDIC }\end{array}$ & $\begin{array}{l}\text { (28 ago. 2009). Proibiu a importação de pneus usados e reformados, } \\
\text { independentemente de sua proveniência. }\end{array}$ \\
\hline
\end{tabular}

Fonte: elaborado a partir de dados colhidos em: Mercosur, 2002; Brasil, 2007; WTO, 2007a; 2007b; Sanchez et al, 2007; Souza, 2010; Oliveira, 2012

Com a decisão, o STF pôs fim à prática de concessão de autorizações judiciais de importação de pneus usados e reformados para o Brasil ${ }^{12}$. O aspecto da "exceção Mercosul" foi um ponto obscuro no julgamento em virtude de discrepâncias entre o voto lido e escrito da Ministra Carmen Lúcia. Posteriormente, no entanto, adotou-se o entendimento de que o STF teria considerado a exceção ao bloco inconstitucional ${ }^{13}$.

Por meio do desfecho no STF, o Poder Executivo conseguiu, de certa forma, barrar as pretensões de fundo das Comunidades Europeias, ao mesmo tempo em que obteve o alinhamento das normas brasileiras às do sistema multilateral de comércio. O Painel e o Órgão de Apelação da OMC, de modo geral, deram razão ao bloco europeu, considerando que o Brasil estava praticando comércio discriminatório e deveria, consequentemente, alterar o formato de sua política, inclusive pela eliminação da "exceção Mercosul". Diante dessa decisão, duas

\footnotetext{
${ }^{12} \mathrm{Na}$ conclusão do voto da Ministra Carmen Lúcia, encontra-se a afirmação de que "a ponderação dos princípios constitucionais demonstra que a importação de pneus usados ou remoldados afronta os preceitos constitucionais da saúde e do meio ambiente ecologicamente equilibrado e, especificamente, os princípios que se expressam nos arts. 170, inc. I e VI e seu parágrafo único, $196 \mathrm{e}$ 225, da Constituição do Brasil." (BRASIL, 2009, p. 123) A ministra posicionou-se pela declaração de constitucionalidade das normas restritivas à importação de pneus usados e remoldados; bem como pela declaração de inconstitucionalidade das interpretações judiciais que permitiram a importação de pneus usados (2009, p. 124).

13 "Ocorre que, durante a sessão de julgamento do dia 24 de junho de 2009, a Ministra fez entender ao Plenário que estaria modificando seu voto para declarar, igualmente, a inconstitucionalidade das interpretações que autorizavam a entrada de pneus remoldados integrantes de países do Mercosul." (SOUZA, 2010, p. 47) A pedido da SECEX, a AGU emitiu parecer entendendo que a exceção aos remoldados provenientes do Mercosul havia sido declarada inconstitucional. No parecer, asseverou que, apesar de o voto da Min. Camen Lúcia registrar a exceção como permitida, em plenário, a ministra haveria verbalizado que as importações de remoldados provenientes do Mercosul também eram inconstitucionais (cf. SOUZA, 2010, p. 47; OLIVEIRA, 2012, p. 136).
} vol.09, nº. 04, Rio de Janeiro, 2016. pp. 1982-2006 1988 
alternativas apresentavam-se: o Brasil poderia liberar o comércio de usados e reformados, ou proibi-lo completamente (SOUZA, 2010, p. 41; OLIVEIRA, 2012, p. 129). Em qualquer caso, a política não poderia permanecer com feições discriminatórias. Valendo-se da decisão do STF, o Poder Executivo seguiu a via da proibição abrangente. Embora com isso o Executivo tenha colocado as normas brasileiras “em ordem” com suas obrigações junto à $\mathrm{OMC}$, o deferimento de sua pretensão pelo STF representou guinada em relação à política anterior de cumprir o laudo arbitral do Mercosul.

\section{REPRESENTAÇÕES INTELECTUAIS DE ENCADEAMENTOS DECISÓRIOS TRANSFRONTEIRIÇOS}

A guerra dos pneus exemplifica a proposição mais abrangente de que a formulação de políticas públicas locais pode sofrer a incidência de articulações e normas oriundas não só de autoridades nacionais, mas também de movimentações deliberativas em espaços internacionais. A variedade de normas e decisões que incidiram sobre a política comercial brasileira aplicável aos pneus está ilustrada no Quadro 2. Houve posições em disputa entre autoridades nacionais, entre estas e organismos internacionais, e ainda embates de organismos internacionais entre si. Tal configuração sugere a necessidade de que encadeamentos decisórios transfronteiriços sejam levados em conta na análise jurídica das políticas públicas locais.

A percepção dessa necessidade implica repensar o modo como o discurso jurídico tende a aproximar-se de políticas públicas. Uma parte das análises jurídicas convencionais se mantém incapaz de abranger (i) normas transnacionais e (ii) o "jogo político" envolvido na gênese normativa. No primeiro aspecto, apenas as normas que integram o ordenamento jurídico nacional são encaradas como expressões de normatividade relevante. No segundo aspecto, apenas o comportamento de instituições nacionais constitucionalmente reconhecidas como "poderes da República" é tido como relevante para a abordagem da formulação das normas que configuram políticas públicas. $\mathrm{O}$ viés presente em ambos os aspectos remete, no fundo, ao formalismo e à tradição jurídica dogmática no Brasil (cf. CASTRO, 2012).

Essa configuração da maneira como o direito aborda políticas públicas implica que elementos empiricamente relevantes, mas não abrangidos pelas formas jurídicas existentes, são deixados de fora. Vale pensar, nesse sentido, que a doutrina de freios e contrapesos se refere apenas ao jogo entre poderes nacionais, e que o direito constitucional reconhece a normatividade apenas de fontes nacionais, ou de tratados internacionais que tenham sido formalmente internalizados. A guerra dos pneus sugere que o direito constitucional não é o "direito máximo" de um país, mas é capaz apenas de tratar de uma dimensão parcial da formatação da política de restrição à importação de pneus usados e reformados. Elementos internacionais não formalmente compreendidos no ordenamento jurídico nacional - como decisões em espaços de solução de controvérsias no exterior - tiveram 
peso relevante. Atores para além dos "poderes da República", ao lado destes, influenciaram os rumos de uma política pública no Brasil.

A presente seção apresenta duas possibilidades distintas - embora interrelacionadas - de representação de encadeamentos decisórios transfronteiriços, que se tornam úteis para os juristas. Elas consistem nas noções de "freios e contrapesos parcialmente internacionalizados" (3.1) e processos de "ordenação jurídica transnacional" (3.2). Cada uma apresenta possibilidades de capturar constrangimentos e influências transnacionais à dinâmica institucional e jurídica envolvida na formatação de políticas públicas, tal qual a política de restrição à importação de pneus usados, aqui adotada como exemplo. Todas elas sugerem, ainda, que o discurso constitucionalista, embora pretenda "capturar" tanto as relações entre poderes quanto a produção normativa, mostra-se insuficiente para os fins a que se propõe.

\section{Freios e contrapesos parcialmente internacionalizados}

A doutrina de freios e contrapesos, que se originou na filosofia política a partir das contribuições de Montesquieu $^{14}$, foi incorporada pelo direito constitucional. É comum associá-la à formulação de separação de poderes, pensada por John Locke. Apesar de certas semelhanças - como na concepção de poderes funcionalmente distintos e na pretensão última de que suas doutrinas servissem como ferramentas de limitação do poder do Estado segundo a noção de governo dividido - as duas doutrinas são marcadamente diferentes. Embora várias sejam as disparidades, uma delas merece destaque. Ao passo que Locke afirma a supremacia do Legislativo, derivando disso uma hierarquia entre poderes, em Montesquieu não há hierarquização, mas condicionamento mútuo entre poderes (cf. CASTRO, 2005; 2006).

O sistema de freios e contrapesos explora a rivalidade e o tensionamento entre poderes como mecanismo para limitação do comportamento de autoridades. Dado que aos poderes são atribuídas capacidades de impedir comportamentos dos demais, o sistema de Montesquieu "induz" à negociação dos interesses divergentes. Não há harmonia, mas conflitos negociados de interesses, que se dão numa arena institucionalizada: "[e]stes três poderes deveriam originar um impasse, uma inação. Mas como, pelo movimento necessário das coisas, são compelidos a caminhar, eles haverão de caminhar em concerto.” (MONTESQUIEU, 1992, p. 179)

Elementos da doutrina de freios e contrapesos integram análises jurídicas convencionais a respeito da produção de normas, que por sua vez estruturam políticas públicas. Eles estão envolvidos na distribuição constitucional de competências, na definição dos procedimentos da elaboração normativa, na possibilidade de verificação judicial da validade das normas produzidas, entre diversos outros aspectos. No entanto, o uso

\footnotetext{
${ }^{14} \mathrm{~A}$ ideia de freios e contrapesos de Montesquieu tem antecedentes que remontam ao pluralismo aristotélico e ao argumento maquiveliano de que uma boa constituição é aquela que incorpora o conflito (e não a articulação harmoniosa) entre poderes (cf. CASTRO, 2005; 2012).
} 
convencionalmente feito da doutrina dos freios e contrapesos não é capaz de gerar representações adequadas do comportamento das instituições e da produção normativa.

Os processos de organização do Estado não são definidos apenas por instituições juridicamente constitucionais. Para além destas, há instituições que de fato dizem "respeito à existência e organização dos cargos de autoridade no seio do Estado", com influência sobre seu comportamento. Nesse sentido, têm caráter politicamente constitucional (CASTRO, 2006, p. 43). A existência de instituições que desempenham papel politicamente constitucional, encontrando-se de fato presentes nos embates pela definição do formato de políticas públicas e das que a estas correspondem, é uma chave para compreender a sugestão de que - assim como ocorreu na guerra dos pneus - as relações de freios e contrapesos entre poderes encontram-se ao menos parcialmente internacionalizadas.

A noção de freios e contrapesos parcialmente internacionalizados (CASTRO, 2006, p. 59) sugere a necessidade de que o olhar jurídico leve em conta certos elementos transnacionais que desempenham peso prático nas elaborações normativas integrantes do que o jurista comumente se refere como "ordenamento jurídico nacional”. Nesse sentido, vale a pena frisar que a política brasileira de restrição à importação de pneus usados contou com influxos transfronteiriços relevantes, sem os quais a alteração das instituições jurídicas correspondentes a essa política não poderia ser adequadamente representada. Ela envolveu ao menos três diferentes eixos de relação (e tensão) entre poderes (ou espaços decisórios).

O primeiro eixo envolveu disputas locais entre autoridades. Este foi o cenário da política aplicável aos pneus durante a década de 1990. O Poder Executivo movimentava-se pela restrição abrangente da importação de pneus usados e reformados. O Poder Judiciário posicionava-se em tensão com os desideratos políticos do Poder Executivo, concedendo liminares e decisões definitivas que configuravam deliberação com impacto normativo em sentido contrário: um conteúdo diferente para a política comercial brasileira.

O segundo eixo envolveu ligaçôes entre espaços institucionais locais e transfronteiriços de decisão. Há duas ocorrências marcantes nesse eixo. Primeiramente, com o laudo arbitral no Mercosul. Após essa decisão, o Executivo modificou as normas que havia editado e inseriu a "exceção Mercosul”. Em segundo lugar, o início da controvérsia na OMC precedeu o momento em que o Executivo provocou o STF para revisão da constitucionalidade da política no Brasil.

Esse desdobramento remete ao terceiro dos eixos sugeridos aqui: o das disputas de espaços decisórios transfronteiriços entre si. O Órgão de Apelação da OMC entendeu que o fato de o Brasil estar cumprindo laudo arbitral do Mercosul ao permitir a importação de remoldados do Uruguai não escusava a inconsistência das normas brasileiras com suas obrigações decorrentes do regime multilateral de comércio. O STF, em linha com essa consideração, derrubou a "exceção Mercosul" como inconstitucional. Nesse sentido, o STF foi o elo de uma disputa indireta entre dois espaços transfronteiriços cujos posicionamentos jurídicos foram percebidos como vol.09, nº. 04, Rio de Janeiro, 2016. pp. 1982-2006 1991 
irreconciliáveis: a OMC e o Mercosul ${ }^{15}$. O conflito normativo permaneceu formalmente não resolvido, embora uma "hierarquia prática" tenha se revelado no fato de o Brasil ter se alinhado ao ordenamento da OMC, e se desalinhado, a esse respeito, com o do Mercosul. De toda forma, o desfecho de indeterminação formal entre espaços transfronteiriços de decisão pode ser lido - tomando-se de empréstimo o referencial de Gregory Shaffer, abordado na subseção a seguir - como um "acordo tácito de deixar as coisas a seu modo (to live and let live)." (SHAFFER, 2013b, p. 48)

\section{Ordenações jurídicas transnacionais}

Além da noção de freios e contrapesos parcialmente internacionalizados, outro referencial que pode ser empregado para incorporar ao discurso jurídico a existência de encadeamentos decisórios transfronteiriços é o de ordenação jurídica transnacional ( transnational legal ordering), proposto por Gregory Shaffer. Shaffer afirma que "em vastas áreas do direito hoje, não é possível compreender a prática e a mudança jurídica domésticas sem compreender a ordenação jurídica transnacional." (2013a, p.2). Os contextos domésticos interagem com normas e processos jurídicos internacionais (2013c, p. 212). "O que está em questão é a efetividade de processos e ordens jurídicas transnacionais, de um lado, e as margens de liberdade que Estados e comunidades (constituencies) não estatais retêm para determinar seu futuro, de outro lado." (2013c, p. 214).

A ideia de ordenação jurídica transnacional não se confunde com a concepção de direito transnacional. No sentido que Phillip Jessup (1956) lhe conferiu, direito transnacional refere-se ao corpo de normas voltadas para situações que não são abrangidas nem pelo direito interno nem pelo direito internacional. Transnacional seria, na concepção de Jessup, o direito voltado à regulação de eventos e atividades tipicamente transnacionais, que escapam a esses outros agrupamentos normativos. Shaffer, porém, refere-se ao direito pensado por Jessup como "direito transnacional das situações transnacionais". Em contraste, a expressão ordenação jurídica transnacional diz respeito a processos de geração e mudança normativa que não necessariamente estão vinculados a situações transnacionais (ou seja, aquelas que escapam ao direito doméstico e ao internacional). Assim, por exemplo, segundo Shaffer, educação primária e serviços municipais de fornecimento de água "são atividades exclusivamente nacionais, mas que podem ser significativamente moldadas pela construção e fluxo transnacional de normas, quer de direitos humanos, do direito neoliberal ou de normas do desenvolvimento." (2013a, p. 8) O que Shaffer propõe é o "direito transnacional como ordenação jurídica transnacional”, não como ordenamento,

\footnotetext{
15 Diz-se "percebidos como irreconciliáveis" porque a afirmação não deixa de ter implicações normativas subjacentes. Os entendimentos do Mercosul e da OMC de fato não podem ser conciliados com a pretensão de fechamento do mercado brasileiro às importações de pneus usados e remoldados. No entanto, se tal pretensão fosse posta de lado - resultando na liberalização deste mercado - as duas decisões poderiam ser simultaneamente cumpridas pelo Brasil: dar acesso, a um só tempo, a pneus provenientes do Mercosul e das Comunidades Europeias, de modo não discriminatório. Evidentemente, tal solução colocaria a perder a vol.09, nº. 04, Rio de Janeiro, 2016. pp. 1982-2006 1992
} 
mas como fenômenos de interação ou, ainda, um modo de compreender a "produção transnacional de normas jurídicas e formas institucionais em campos específicos e sua migração transfronteiriça, independentemente de serem voltadas a atividades transnacionais ou puramente nacionais." (2013a, p. 6)

As ordens jurídicas domésticas são vistas como permeáveis entre si e sujeitas a processos jurídicos transnacionais ${ }^{16}$. Por meio destes processos, "a construção e transporte transnacional de normas jurídicas acontece." (2013a, p. 8). Tais normas não viajam espontaneamente. Os processos jurídicos transnacionais são impulsionados - e obstacularizados - por atores de tipos variados: agentes governamentais, secretariados de organizações internacionais, profissionais, empresários e ativistas da sociedade civil (2013a, p. 8). Isso permite compreender por que a ordenação jurídica transnacional não se refere a um corpo específico de normas: o processo de gênese e deslocamento de normas é feito segundo os campos específicos em que os atores se movimentam, afetando as áreas mais diversas do direito. Shaffer destaca, ainda, que os processos jurídicos transnacionais têm caráter "recursivo" 17 significando que "o transnacional e o nacional são interpenetrados em um dado setor de atividade", em diálogos e atritos multidirecionais e dinâmicos (2013b, p. 45, p. 214):

o transnacional e o nacional se situam em tensão, com atores em processos jurídicos transnacionais buscando influenciar a prática e a elaboração normativa local, e em que normas jurídicas nacionais, adaptações e resistências fornecem modelos para, e retroalimentam, a elaboração jurídica transnacional. (2013a, p. 13)

Assim, na concepção de Shaffer e seus colaboradores, não há um só sentido de migração ou influência normativa. Não se trata apenas de conceber encadeamentos "de cima para baixo" ou "de fora para dentro". A dinâmica nacional pode afetar processos e normas transnacionais tanto quanto o contrário é possível (SHAFFER, 2013c, p. 214).

A proposta de Shaffer implica rejeitar a visão de que a produção normativa local possa ser vista de modo atomizado, isolada das interferências de processos mais amplos de ordenação jurídica transnacional. Não só as normas jurídicas, como o comportamento das instituições, passam a poder serem vistas como compreendido num jogo recursivo em que o nacional e o transacional encontram-se em contato, e sujeitos a influências mútuas.

estratégia do poder Executivo para o setor, iniciada na década de 1990. Considerações adicionais a esse respeito são feitas na seção 3.2 .

${ }^{16}$ Shaffer destaca 5 dimensões de mudanças induzidas transnacionalmente: (i) no direito substantivo e na prática jurídica; (ii) na definição das fronteiras entre Estado, mercado e outras formas de organização social; (iii) na arquitetura institucional estatal; (iv) na expertise profissional e no papel desempenhado por experts na administração (governance); e (v) "nos padrões associativos, institucionalizados por mecanismos transnacionais de accountability com suas respectivas molduras jurídicas. ” (2013b, p. 23). Estas dimensões encontram-se interligadas, "porque mudanças numa delas catalisam mudanças noutras. Por exemplo, processos jurídicos transnacionais podem fazer incidir novas demandas sobre o Estado ao impulsionar a autoridade de certas formas de expertise, o que, por sua vez, cria pressões por mudança na alocação de autoridade entre instituições estatais, ou sobre a fronteira entre o Estado e a ordenação privada." (2013b, p. 25).

${ }^{17}$ Castro (2014, p. 7) aponta que a teoria da ordenação jurídica transnacional de Gregory Shaffer refina conceitualmente a noção de recursividade jurídica apresentada por Terrence Halliday e Bruce Carruthers (2007). No contexto da contribuição desses autores, a recursividade é a categoria que expressa elaborações jurídicas como resultado de múltiplas e reiteradas interações entre o global e o local. 
As categorias propostas pelo referencial das ordenações jurídicas transnacionais fornecem outras possibilidades de observar os três eixos de interação mencionados na subseção anterior, momento em que foram abordados desde a noção de freios e contrapesos parcialmente internacionalizados. Dessa forma, pode-se conceber que tanto o direito substantivo quanto a arquitetura institucional no Brasil tiveram engastes jurídicos transnacionais ao longo da "guerra dos pneus", inclusive com manifestações de recursividade.

No aspecto do direito substantivo, as normas jurídicas envolvidas na política brasileira de importação de pneus não se originaram exclusivamente de imputs nacionais. Movimentações normativas nacionais afetaram, num primeiro momento, interesses uruguaios, que se valeram do Mercosul para imprimir novo conteúdo às normas brasileiras. Por sua vez, o "novo conteúdo" fomentou o argumento europeu de que o Brasil conduzia, sob o manto formal do embasamento ambiental e sanitário para a restrição aos pneus, uma política comercial seletiva, dados os fluxos de importação autorizados judicialmente e pela "exceção Mercosul". Esse argumento foi bemsucedido no desfecho da controvérsia da OMC, tendo representado constrangimento eficaz sobre o comportamento do STF e do Executivo no Brasil e resultado em ainda outro formato para a política dos pneus. Nesse jogo, os outputs de uma esfera serviram como inputs em outras, fomentando novas movimentações deliberativas. A guerra dos pneus configurou, portanto, uma dinâmica normativa transnacional com instâncias de recursividade.

No aspecto da arquitetura institucional, o referencial de ordenação jurídica transnacional e a categoria de recursividade oferecem possibilidade curiosa de leitura das relações entre o Executivo e o Judiciário. Na década de 1990, magistrados da Justiça Federal efetivamente frustraram as pretensões do Executivo por uma política restritiva, autorizando a importação em larga escala de pneus usados, ainda que tais autorizações fossem concedidas caso a caso. O Executivo limitou-se a recorrer das decisões judiciais, valendo-se das estruturas do próprio Judiciário. Quando o tema chegou à atenção da OMC, porém, o relacionamento entre o Executivo e o Judiciário brasileiro foi relevantemente reconfigurado. De certo modo, o Executivo conseguiu, a partir dos "constrangimentos" representados pelas normas do sistema multilateral de comércio e da possibilidade de condenação na $\mathrm{OMC}$, fazer prevalecer o conteúdo de política inicialmente pretendido: a restrição geral à importação de usados. O STF, ao chancelar, via declaração de constitucionalidade, as normas originalmente editadas pelo Executivo, "disciplinou” magistrados da Justiça Federal e faz cessar a concessão de liminares. A leitura possível, nesse sentido, é o de que o "constrangimento" externo, representado pela OMC, alavancou, no jogo nacional dos poderes, a posição do Executivo frente ao Judiciário. A dinâmica institucional nacional foi significativamente afetada por fatores transfronteiriços.

Parece claro, a partir destas caracterizações, que as abordagens da guerra dos pneus feitas a partir de noções de freios e contrapesos parcialmente internacionalizados e de ordenações jurídicas transnacionais são convergentes. 


\section{OUTROS PROCESSOS TRANSFRONTEIRIÇOS JURIDICAMENTE RELEVANTES}

Para além de freios e contrapesos parcialmente internacionalizados e de ordenações jurídicas transnacionais, há outros processos transfronteiriços juridicamente relevantes, mas pouco abordados por perspectivas jurídicas convencionais. Entre tais processos, encontram-se a deflexão monetária interportfólio e a elaboração de indicadores globais, abordados nas subseções seguintes.

\section{Modulações normativas da deflexão monetária interportfolio}

A categoria da deflexão monetária interportfolio ${ }^{18}$ integra o instrumental da Análise Jurídica da Política Econômica (AJPE), uma corrente interdisciplinar de direito e economia que, entre seus contornos principais, focaliza a fruição empírica de direitos subjetivos, propõe uma noção de justiça econômica articulada em termos jurídicos (fruição equânime de direitos de produção e de consumo), e reformula categorias jurídicas para gerar novas metodologias de análise (cf. CASTRO, 2009; 2011; 2013).

A AJPE concebe a economia de mercado em termos de agregados contratuais. Ao invés de enxergar os contratos de modo atomizado, a proposta é encará-los em redes de contratos entrecruzados (CASTRO, 2011, p. 19) que alcançam as relações internacionais (CASTRO, 2009, p. 40). A nova análise contratual, também chamada de análise de portfólio, é o instrumental proposto pela AJPE para representar a arquitetura dos agregados contratuais, o que é feito com auxílio de uma matriz que permite explicitar, ao longo de um eixo, os conteúdos da economia real (cláusulas de utilidade ${ }^{19}$ ) e monetária (cláusulas monetárias ${ }^{20}$ ) e, ao longo de outro, os conteúdos provenientes de negociação privada (conteúdos de interesse privado ${ }^{21}$ ) e da deliberação pública (conteúdos de interesse público ${ }^{22}$ ).

\footnotetext{
${ }^{18}$ A deflexão monetária interportfolio é também referida como transmissão intercontratual de valores monetários.

${ }^{19}$ Cláusulas de utilidade são objetos dos contratos que refletem "interesses materiais da economia real". "No caso dos contratos financeiros, os conteúdos da cláusula de utilidade serão também ativos monetários. " (2011, p. 21) "A obrigação das indústrias de alimentos de incluírem, nos rótulos de seus produtos, declaração sobre nutrientes” é um exemplo de cláusula de utilidade (CASTRO, 2009, p. 36).

${ }^{20}$ Cláusulas monetárias são objetos do contrato que incorporam "interesses materiais que adquirem forma monetária. " (CASTRO, 2011, p. 21). Correspondem, dessa forma, a uma prestação pecuniária ou obrigação financeira (CASTRO, 2009, p. 32), a exemplo de preços, tributos e outras prestações pecuniárias como taxas de juros e de câmbio.

${ }^{21}$ Os conteúdos de interesse privado têm como principal característica serem, em princípio, livremente negociados e não sujeitos a exigências de ampla publicidade. (CASTRO, 2009, p. 34; cf. 2011, p. 21).

${ }^{22}$ Conteúdos de interesse público são determinados por procedimentos sujeitos a publicidade ampla, como pela via legislativa, administrativa ou judicial. (CASTRO, 2009, p. 34; cf. 2011, p. 21). Tais conteúdos correspondem a a "exigências técnicas e normativas constitutivas das 'políticas públicas"” (2011, p. 22; cf. 2013, p. 23) e da política econômica.
} 
Quadro 3 - Matriz da Nova Análise Contratual

\begin{tabular}{|l|c|c|}
\hline & $\begin{array}{c}\text { Cláusula de } \\
\text { Utilidade }\end{array}$ & $\begin{array}{c}\text { Cláusula } \\
\text { Monetária }\end{array}$ \\
\hline Interesse Privado & $\mathrm{U}$ & $\mathrm{M}$ \\
\hline Interesse Público & $\mathrm{U}$ & $\mathrm{M}$ \\
\hline
\end{tabular}

Fonte: CASTRO (2013,p. 17; 2011, p. 42)

Pode-se, a título de exemplo, utilizar a matriz para análise do contrato de compra e venda de pneus entre uma empresa e o consumidor final, com a ressalva de que o delineamento de conteúdos não pretende ter caráter exaustivo:

\section{Quadro 4 - Exemplo de aplicação da Matriz da Nova Análise Contratual}

\begin{tabular}{|c|c|c|}
\hline & Cláusula de Utilidade & Cláusula Monetária \\
\hline $\begin{array}{l}\text { Interesse } \\
\text { Privado }\end{array}$ & $\begin{array}{l}\text { - } \quad \text { o pneu comercializado; } \\
\text { - } \quad \text { Eventual serviço de instalação; } \\
\text { - } \quad \text { Eventual garantia adicional fornecida pela } \\
\text { empresa. }\end{array}$ & $\begin{array}{l}\text { - } \text { O preço cobrado do } \\
\text { consumidor. }\end{array}$ \\
\hline $\begin{array}{l}\text { Interesse } \\
\text { Público }\end{array}$ & $\begin{array}{l}\text { - Padrões da ABNT de medidas e segurança; } \\
\text { - } \quad \text { Obrigações de destino ambiental adequado } \\
\text { de pneus inservíveis por pneus novos ou remoldados } \\
\text { introduzidos no mercado. }\end{array}$ & $\begin{array}{l}\text { Tributos incidentes sobre a } \\
\text { transação, inclusive tarifas aplicáveis ao } \\
\text { comércio exterior; } \\
\text { - Taxa básica de juros da } \\
\text { economia. }\end{array}$ \\
\hline
\end{tabular}

Cabe explicar, no quadro acima, o posicionamento da taxa básica de juros da economia como componente $\mathrm{M}$ ' do contrato de compra e venda de pneus. O produtor e o revendedor sempre enfrentam a possibilidade de destinação alternativa do capital que investem na produção e comercialização dos pneus. Assim, ao invés de investir na compra de um estoque de pneus - ou no pagamento dos fatores para produzi-los - estes empresários, diante de eventual maior rentabilidade dos investimentos financeiros em relação aos investimentos no setor de pneus, podem optar pelo "desinvestimento" da produção. Nesse caso, retiram seu capital da economia real e passam a obter retornos especulativos na economia monetária (cf. CASTRO, 2011, p. 23-4). 
A noção de deflexão monetária interportfolio sugere a existência de "interconectividades contratuais que estabelecem múltiplos vínculos entre a economia real e a economia monetária, tanto em sua dimensão local quanto na internacional” (CASTRO, 2006, p. 60). São nexos (CASTRO, 2010, p. 162) ou engastes monetários entre contratos distintos. Nesse sentido, as mudanças ocorridas nos conteúdos monetários de contratos posicionados num ponto de um agregado contratual transmitem impactos sobre os demais contratos que o integram. As sinalizações de preços, nesse sentido, "viajam" pelas redes contratuais por meio da transmissão intercontratual de valores monetários, ou seja, em razão de deflexões monetárias. Em especial, "o preço do dinheiro e dos ativos financeiros (taxas de juros) espalham-se de maneira rápida e abrangente pelas redes contratuais." (CASTRO, 2014, p. 29) Assim, a deflexão monetária interportfolio ocorre, por exemplo, quando a empresa, diante de aumentos na conta de energia elétrica, reajusta preços dos contratos de compra e venda daquilo que produz (cf. CASTRO, 2014, p. 29), ou quando o aumento na taxa de juros desestimula o investimento produtivo e cria incentivos para a especulação financeira, como sugerido no parágrafo anterior.

\section{Quadro 5 - representação da deflexão monetária interportfolio}

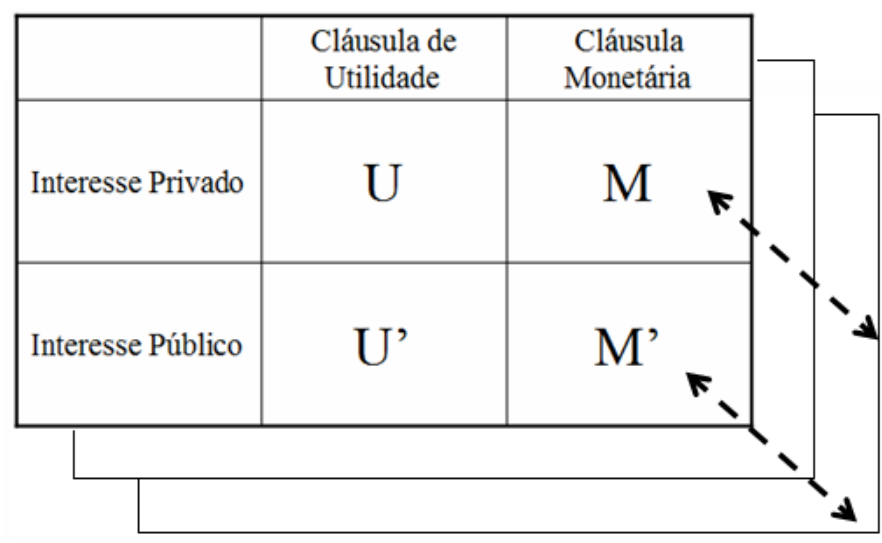

Decisões sobre políticas públicas e medidas de políticas econômicas podem incidir sobre o conteúdo M' dos agregados contratuais e transmitir efeitos em cadeia. Assim, a política de restrição à importação de pneus usados representou um ônus monetário relevante para as empresas que fabricavam pneus remoldados no Brasil.

Com efeito, para tais empresas, a importação de pneus usados da Europa como insumos para sua produção local era mais barata (inclusive pela "falta de infra-estrutura, como postos de coleta dos pneus") e fornecia material de melhor qualidade ("em razão principalmente do péssimo estado das estradas brasileiras") do que os provenientes de fontes brasileiras (BRASIL, 2009, p. 118). A restrição ao acesso de fornecedores europeus de pneus usados representava, portanto, o encarecimento da produção de remoldados no Brasil. Essa decisão transmite efeitos monetários em cadeia.

Em geral, remoldados e novos concorrem nos mercados como bens substitutos. Majorações no preço de 
um deles tende a fazer com que a demanda pelo outro aumente. A política comercial brasileira, ao causar aumento dos custos de produção dos remoldados, representou incentivos à procura por pneus novos, que passaram a ter menor diferença de preço em relação aos remoldados.

Nesse ponto, cabe considerar que a decisão de barrar a importação de usados como insumo da produção de remoldados afeta a economia brasileira em geral. A matriz de transportes no Brasil é majoritariamente escorada no modal rodoviário, responsável por mais de 60\% dos fretes (WANKE; FLEURY, 2006, p. 418). O Registro Nacional do Transporte Rodoviário de Cargas, da Agência Nacional de Transportes Terrestres (ANTT) contabiliza, atualmente, mais de 2,2 milhões de veículos utilizados no transporte de cargas no Brasil, como caminhões, furgões, caminhonetes e outros utilitários. (BRASIL, 2015). Um componente adicional desse contexto é a informação de que, para as empresas, o "transporte representa, em média, 64\% dos custos logísticos, 4,3\% do faturamento, e em alguns casos, mais que o dobro do lucro" (WANKE; FLEURY, 2006, p. 409).

Dessa forma, na ausência de alterações em outras variáveis, o aumento nos custos da aquisição de pneus para o transporte rodoviário no Brasil, pelo encarecimento da opção "remoldados", deflete-se monetariamente em cadeia pelos contratos da economia. Não só porque os bens em circulação são bastante dependentes dos fretes rodoviários, como também porque o transporte urbano de pessoas incorpora o custo dos pneus em sua operação. Pode-se pensar, assim, em "duplo efeito" sobre os custos das empresas: o transporte dos materiais e da mão-deobra envolvidos na produção é encarecido.

Este é apenas um dos aspectos da deflexão monetária interportfolio, que é modulada a partir da decisão de permitir ou não a importação de pneus usados (ou remoldados). Pode-se ainda considerar os efeitos em cadeia destas decisões sobre a existência de postos de trabalho nos setores industriais e comerciais relacionados a pneus novos e remoldados (com os subsequentes efeitos sobre renda da população, consumo nos mercados locais, arrecadação tributária etc.), tanto no Brasil como no exterior; custos ambientais ligados à existência de pneus usados não reaproveitados (danos ambientais; custos com aterros sanitários e outras formas de reaproveitamento, como na pavimentação de estradas ou na construção civil); entre outros.

Diante das deflexões monetárias ao longo das cadeias contratuais, torna-se possível compreender como decisões tomadas em espaços transfronteiriços podem, por sua incidência sobre a formação e transmissão de preços, afetar diversos contratos da economia brasileira. Nesse sentido, tanto o laudo arbitral do Mercosul quanto as decisões do órgão de solução de controvérsias na $\mathrm{OMC}$, ao afetarem os componentes $\mathrm{M}$ e $\mathrm{M}$ ’ dos agregados contratuais, disparam efeitos em cadeia, em maior ou menor proporção. Tais efeitos podem reorientar atividades econômicas, rumos dos investimentos, gerar empregos em alguns setores, fechar postos de trabalho em outros etc.

Pode-se perceber que os efeitos provocados pela deflexão monetária se ligam às condições de competitividade de bens e serviços. Os efeitos da competição - inclusive internacional - podem alcançar pontos sensíveis à organização econômica, social e jurídica de países e regiões. Assim, por exemplo, a ameaça ou vol.09, no. 04, Rio de Janeiro, 2016. pp. 1982-2006 1998 
fechamento de empresas e postos de trabalho de um setor, frente à competição de outro (ou de competidores internacionais no mesmo setor), se tornada politicamente relevante, pode resultar na adoção de medidas estratégicas por parte dos Estados. Nesse sentido, medidas de políticas públicas e de política econômica podem estar voltadas a construir um "ambiente institucional monetário estratégico", com a finalidade de proteger ou fomentar certas práticas econômicas e sociais. Tais medidas envolvem modulações deliberadas da deflexão monetária interportfolio, como pela aplicação de barreiras tarifárias, abertura de linhas de empréstimo com taxas de juros preferenciais, concessão de isenções tributárias, intervenções cambiais e outros modos de proteção e fomento. Em outros termos, o "ambiente institucional monetário estratégico" - ou simplesmente "moeda estratégica", compreende:

Instrumentos e políticas que se traduzem em conteúdos de 'estratégia' do Estado e, em tese, expressam o interesse público ('pactos sociais'), seja para ampliar a competitividade de investimentos [...], seja para proteger práticas de consumo [...], seja, ainda, para adquirir posições estratégicas nas relações econômicas internacionais. (CASTRO, 2009, p. 59)

A aplicação dessa noção permite ler a intenção do Executivo brasileiro de cessar importações de pneus usados e remoldados no contexto da "guerra dos pneus" como medida integrante da "moeda estratégica", resultando em modulações nas condições de competitividade entre os setores de produção de novos e remoldados no Brasil, e em efeitos sobre as cadeias de produção (e disposição final dos resíduos) de pneus no exterior. Pela via da deflexão monetária interportfolio, tais modulações afetam a distribuição de renda entre os setores produtivos mencionados, com efeitos sobre empregos, arrecadação tributária e mesmo sobre variáveis ambientais, sanitárias etc.

\section{Implicações normativas da produção e emprego de indicadores}

Um dos elementos da fundamentação do voto da Ministra Carmen Lúcia, relatora da ADPF 101, foi a relação estabelecida entre pneus e doenças como a febre amarela e a dengue:

As pesquisas e as estatísticas são taxativas ao comprovar os riscos à vida acarretados pelas doenças tropicais, em especial a dengue, que tem como uma de suas principais causas exatamente a presença de resíduos sólidos, como os pneus, não utilizados e não descartados de forma a garantir a salubridade. (BRASIL, 2009, p. 105)

A Ministra considerou dados do Ministério do Meio Ambiente, que informavam a existência de "100 milhões de pneus abandonados no território brasileiro como passivo a ser tratado” (2009, p. 121), e do Ministério da Saúde, que "registrou, em 2007, 559.954 casos suspeitos de dengue; 1.541 casos confirmados de Febre Hemorrágica da Dengue (FHD) e 158 óbitos por FHD, com uma taxa de letalidade para FHD de 10,2\%” (2009, p. 144).

Esta é apenas uma amostra da presença de estatísticas nos documentos envolvidos na ADPF 101. As contribuições das organizações da sociedade civil que participaram no processo como amici curiae foram ainda 
mais prolíficas na apresentação de números. Como se pode observar no trecho destacado acima, estatísticas foram empregadas como suporte ao procedimento de ponderação de princípios que levou ao reconhecimento da prevalência do "direito à saúde" e ao "ambiente equilibrado" sobre o princípio da "livre iniciativa", no desfecho do caso.

A influência dos números sobre decisões judiciais evidencia a atratividade que indicadores têm para a estruturação de políticas públicas. Essa "atratividade", no fundo, reflete o caráter normativo que os índices podem exercer em diferentes contextos, desde a concepção (formulação de metas, planos e projetos) de políticas até a avaliação de seus resultados. Na medida que índices produzidos por "autoridades globais" - muitas das quais privadas $^{23}$ - têm alcance transfronteiriço e influência prática sobre o comportamento de governos e outras organizações, também eles integram encadeamentos decisórios transfronteiriços.

Existe uma literatura jurídica que se ocupa do papel normativo assumido pelos índices. Em governance by indicators, Davis, Kingsburry e Merry "estudam efeitos da quantificação e dos indicadores sobre tomada de decisões, alocação de recursos, categorias sociais, formas de contestação e poder de experts no interior e através das instituições." (2012, p. 4). A produção e uso de indicadores são vistos como atividades relevantes para influenciar as formas, o exercício e a distribuição de poder no globo.

Um indicador é uma coleção nomeada de dados ordenados que pretende representar o desempenho passado ou projetado de diferentes unidades. As informações são geradas por um processo que simplifica dados brutos sobre um fenômeno social complexo. Os dados, nessa forma simplificada e processada, podem ser usados para comparar unidades específicas de análise (como países, instituições ou corporações), de modo sincrônico ou ao longo do tempo, e para avaliar seu desempenho tendo por referência um ou mais padrões. (DAVIS; KINGSBURRY; MERRY, 2012, p. 6)

A simplificação de um fenômeno social complexo é uma das características centrais para o apelo e o impacto dos indicadores, que são "tipicamente dirigidos a formuladores de políticas e destinados a ser convenientes, fáceis de compreender e de usar." (2012, p. 8) Nesse sentido, parte da atratividade dos indicadores reside no fato de que eles desempenham uma função heurística na tomada de decisões. Outra parte dessa atratividade reside no fato de que indicadores podem ser empregados como medida do sucesso ou fracasso daqueles que tomam decisões. Conforme ressaltam Davis, Kingsburry e Merry indicadores definem padrões, geralmente expressos nos nomes dos indicadores: corrupção, proteção aos direitos humanos, respeito ao rule of law, entre outros. (2012, p.9).

\footnotetext{
${ }^{23} \mathrm{O}$ tema da "regulação privada" global, que remete ao exercício transfronteiriço de autoridade por entes privados, é discutido na obra The new global rulers: the privatization of regulation in the world economy (BÜTHE; MATTLI, 2011). Entre os exemplos discutidos no livro, estão o estabelecimento de padrões contábeis para relatórios financeiros pela International Accounting vol.09, no. 04, Rio de Janeiro, 2016. pp. 1982-2006 2000
} 
Outro ponto a ser destacado sobre o uso de indicadores como instrumento de governança é que tais instrumentos podem encobrir relações e disputas de poder. Assim, apesar de passarem a impressão de que, por serem expressões quantitativas de um fenômeno, os indicadores são critérios objetivos para o planejamento e a avaliação de políticas públicas, seu uso "obscurece as disputas sociais e políticas incrustadas em sua formação" (2012, p. 19), que não se tornam evidentes em seu nome. De todo modo, decisões baseadas em indicadores podem ser apresentadas ao público como "eficientes, consistentes, transparentes, científicas e imparciais." (2012, p. 16)

Há vários meios pelos quais a autoridade pode ser exercida para além das fronteiras de um só Estado, de modo a influenciar comportamentos, a produção e a distribuição de recursos. Entre eles estão "ações militares, transferências de fundos, promulgação de instrumentos jurídicos, publicação de relatórios científicos, campanhas publicitárias ou programas educacionais. " (2012, p. 11) Estes são meios para o exercício de influências de diferentes tipos, como a fisica (envolvendo ameaça ou uso de força); econômica (mobilização de recursos materiais); social (habilidades para alterar relações de um ator com os demais) e aquela que se torna, aqui, a mais relevante: a científica ou moral, que envolve a persuasão dos méritos de se fazer algo (2012, p. 11-2).

A produção de indicadores envolve ainda asserções de poder de experts em determinadas áreas, que podem ser mais ou menos bem-sucedidos em influenciar o comportamento de atores "geograficamente dispersos" (2012, p. 13-5). O poder dos experts em fixar padrões via indicadores, e definir escalas quantitativas de "melhor" e "pior", em relação às quais o comportamento de governos, políticas públicas e instituições jurídicas serão avaliados, posiciona-se de modo alternativo a procedimentos de votação e barganha política que remetem às urnas. Essa tensão é facilmente perceptível, por exemplo, nos índices de classificação de risco dos títulos da dívida pública produzidos por agências privadas como a Moody's, a Fitch Ratings e a Standard \& Poor's. As notas do risco da dívida de países operam, muitas vezes, como contraponto a anseios populares manifestos nas urnas. Políticas redistributivas tendem a ser percebidas pela comunidade de investidores como ameaças, no longo prazo, à segurança e à rentabilidade dos investimentos, sendo estas últimas favorecidas por Estados que adotem medidas "saneadoras", tais como a disciplina fiscal, controle da inflação e medidas correlatas (cf. CASTRO, 2006). Nesse sentido, como parece ser o caso da "guinada" recente na política econômica brasileira, governos podem ver-se constrangidos a mudar a orientação de sua plataforma política em relação aos projetos ventilados durante a disputa eleitoral, diante de perspectivas de rebaixamento de notas e perda do "grau de investimento": um rótulo produzido pelas referidas agências. Essa configuração das possibilidades de ação estratégica dos governos encontra-se relacionada a outra afirmação dos autores, segundo os quais:

Limitações na habilidade de contestar o exercício de poder por tomadores globais de decisão tendem a alterar o

Standards Board (IASB) e de padrões técnicos de produção e controle de qualidade pela International Organization for vol.09, no. 04, Rio de Janeiro, 2016. pp. 1982-2006 
balanço de poder em favor dos experts "técnicos", quer dizer, pessoas com expertise na construção e análise de indicadores. (DAVIS; KINGSBURRY; MERRY, 2012, p. 19)

As considerações acima evidenciam que, para além de encadeamentos decisórios com espaços transfronteiriços como o Mercosul e a $\mathrm{OMC}$, a formulação de políticas públicas e a estruturação das instituições jurídicas encontram-se perpassadas por influências de ordem técnica ou científica, que assumem expressão ostensiva na forma de índices. No caso da guerra dos pneus, o uso de dados quantificados em apoio a raciocínios formalizados de "ponderação de princípios" é apenas sugestivo dessa influência. Para além disso, índices relativos a saúde e doenças, proteção ambiental e sustentabilidade, liberdade de comércio internacional e facilidade de fazer negócios no país podem ser levados em conta na formatação de uma política pública como a política comercial de restrição à importação de pneus usados e reformados. Não se trata, aqui, de afirmar que indicadores como aqueles exemplificados no Quadro 6 tenham desempenhado influência identificável na "guerra dos pneus", mas de sugerir que, para além de espaços arbitrais e judiciais, também os indicadores podem integrar o jogo do exercício transfronteiriço de autoridade e, consequentemente, incidir sobre a formatação das instituições jurídicas - como a proibição ou liberação da importação de pneus.

\section{Quadro 6 - Alguns indicadores pertinentes a uma política de restrição à importação de pneus}

\begin{tabular}{|c|c|c|}
\hline $\begin{array}{c}\text { Nome do } \\
\text { Indicador }\end{array}$ & Produtor & Aspecto relevante \\
\hline $\begin{array}{c}\text { World Health } \\
\text { Statistics }\end{array}$ & $\begin{array}{c}\text { Organização Mundial de } \\
\text { Saúde }\end{array}$ & $\begin{array}{c}\text { Avalia países segundo "doenças infecciosas selecionadas" } \\
\text { (WHO, 2015) }\end{array}$ \\
\hline Doing Business & Banco Mundial & $\begin{array}{c}\text { Avalia países segundo a facilidade de fazer negócios, que inclui } \\
\text { rankingsobre liberdade de comércio internacional. (Banco } \\
\text { Mundial, 2015) }\end{array}$ \\
\hline $\begin{array}{c}\text { Index of Economic } \\
\text { Freedom }\end{array}$ & Heritage Foundation & $\begin{array}{c}\text { Avalia liberdade econômica nos países. Emprega } \\
\text { quantificações relativas a "abertura dos mercados" e "liberdade } \\
\text { comercial" como componentes da medição agregada de } \\
\text { "liberdade econômica". (Heritage Foundation, 2015) }\end{array}$ \\
\hline $\begin{array}{c}\text { Environmental } \\
\text { Performance Index }\end{array}$ & $\begin{array}{c}\text { Universidades de Yale e } \\
\text { Columbia / Fórum } \\
\text { Econômico Mundial }\end{array}$ & $\begin{array}{c}\text { Avalia o desempenho ambiental de países com base em 20 } \\
\text { indicadores ambientais, dentre os quais impactos do ambiente } \\
\text { sobre a saúde humana. (YCELP, 2015) }\end{array}$ \\
\hline
\end{tabular}


As limitações, discutidas até aqui, de análises mais convencionais sobre a formação e reforma de políticas locais não têm passado despercebidas. Segundo David Lake, por exemplo, as abordagens convencionais sobre a elaboração normativa partem de uma noção "formal-legal" de soberania que, ao concebê-la como exercício supremo do poder político em uma circunscrição territorial, tende a excluir influências de outros atores sobre o que acontece no território do Estado. "Os acadêmicos tradicionalmente compreendem a soberania de modo a implicar que os Estados sejam as supremas autoridades no interior de seus domínios territoriais exclusivos." (2010, p. 597). Uma alternativa a essa visão consiste em descrever a soberania não como suprema, mas contingente (2010, p. 598-9). Nessa concepção mais flexível de soberania, o Estado passa a ser visto como mais uma autoridade em meio a outras, abrindo espaço para a percepção de exercícios práticos de poder por "autoridades globais". As atividades destas, ainda que não caracterizem produção formal de normas jurídicas, podem revestir-se de implicações normativas incidentes sobre o comportamento dos Estados, a formatação de políticas públicas e das instituições jurídicas correlatas. Este é o caso de entidades que conseguem extrair consequências políticas a partir do conhecimento articulado na forma de indicadores.

\section{CONSIDERAÇÕES FINAIS}

A "guerra dos pneus" foi abordada nesse artigo como modo de evidenciar a existência de encadeamentos decisórios e outros processos transfronteiriços na definição do conteúdo de políticas públicas. Claramente, tais processos transfronteiriços foram mobilizados e repercutiram de várias maneiras sobre as restrições às importações de pneus aplicadas no Brasil desde a década de 1990.

O presente artigo ressaltou que, para além do formalismo jurídico na área do direito internacional - que restringe a abrangência das análises jurídicas, limitando sua capacidade de alcançar elementos concretamente relevantes na dinâmica institucional e estimulando, assim, a proliferação de "pontos cegos" nos esforços analíticos - há alternativas não formalistas para a consideração jurídica de encadeamentos decisórios e outros processos transfronteiriços. Foram apontadas quatro formulações e objetos de análise úteis para tal finalidade: as noções de (i) freios e contrapesos parcialmente internacionalizados, (ii) ordenações jurídicas transnacionais, (iii) modulaçães normativas da deflexão monetária interportfolioe (iv) formulação e difusão do uso de indicadores.

A percepção de que estes elementos existem e que são de fato relevantes para a trajetória assumida pelas políticas públicas é um primeiro passo na pretensão de resgatar a relevância do direito como balizador destas. Ajudam a fazer avançar os esforços de explicitação das relações entre os usos do direito e suas consequências econômicas em escala global. Um segundo passo, mais complexo, consistiria em elaborar ferramentas jurídicas que permitissem seu uso prático na orientação de tais elementos. A percepção de que a produção normativa local é perpassada por encadeamentos decisórios e outros processos transfronteiriços, inclusive a elaboração e difusão 
do uso de indicadores globais, não implica que o discurso jurídico deva se resignar a reconhecer a normatividade destes e relegar-se ao papel de realizar as transformações correspondentes nas instituições jurídicas. Remediar os "pontos cegos" ou "furos" aqui referidos pode ser, ao contrário, um primeiro passo para que o discurso jurídico seja capaz de originar referenciais normativos para esses mesmos fenômenos.

\title{
LEGAL RELEVANCE OF DECISION-MAKING LINKAGES AND OTHER TRANSBOUNDARY PROCESSES: THE EXAMPLE OF THEIR IMPACT UPON BRAZILIAN TRADE BARRIERS IN THE “TIRES WAR”
}

\begin{abstract}
Conventional legal analyses of local policies often rely on formalistic approaches to the domestic legal order. This paper suggests the existence of limitations or "blind spots" in such conventional legal approaches to local policies, which translate into analytical shortfalls regarding cross-boundary processes of determination of the content and structure of legal norms pertaining to local policymaking. The study takes as an example the analysis of a trade policy of import restriction applied to automotive tires adopted in Brazil since the 1990s. The unfolding conflicts regarding this policy, which became known as the "tires war", exemplify the relevance of decision linkages, comprising interactions and tensions among domestic and cross-boundary sources of decision. The paper argues that legal discourse may factor in cross-boundary decision linkages by means of various intellectual tools. Among the possibilities, the paper covers aspects of the notion of partially internationalized checks and balances, the framework of transnational legal ordering (TLO) and of the concept of interportfolio monetary relay. The relevance of cross-boundary decision linkages also prompts the discussion on the role played by global indicators in norm determination, which is shown to be yet another blind spot in conventional legal approaches to local policy-making.
\end{abstract}

Keywords: Checks and balances. Law and international relations. Transnational legal ordering. International trade. Tires war.

\section{REFERENCIAS}

ABRAMOVAY, Pedro Vieira. Separação de poderes e medidas provisórias. Rio de Janeiro: Elsevier, 2012.

BANCO MUNDIAL. Doing business: classificação das economias. 2015. Disponível em: <http://portugues.doingbusiness.org/rankings >. Acesso em: 19 jun. 2015.

BRASIL. Agência Nacional de Transportes Terrestres. Registro Nacional do Transporte Rodoviário de Cargas: RNTRC em números. 16 jun. 2015. Disponível em: <http://www.antt.gov.br/index.php/content/view/4969/RNTRC_em_Numeros.html>. Acesso em: 16. jun. 2015.

Supremo Tribunal Federal. Ação de Descumprimento de Preceito Fundamental [ADPF] 101/DF. Tribunal Pleno. Relatora: Min. Carmen Lúcia. Decisão de 24 jun. 2009. Disponível em: <http://www.stf.jus.br>. Acesso em: 17 set. 2014. 
BÜTHE, Tim; MATTLI, Walter. The new global rulers: the privatization of regulation in the world economy. Princeton: Princeton University Press, 2011.

CASTRO, Marcus Faro de. O Supremo Tribunal Federal e a judicialização da política. Revista Brasileira de Ciências Sociais, vol. 12, no. 34, 1997, p. 147-156. 180,2005

Violência, medo e confiança: do governo misto à separação de poderes. Revista Forense, vol. 382, p. 157-

Instituições econômicas: evolução de seus elementos constitucionais na sociedade de mercado. Revista

de Direito Empresarial. Curitiba, n. 6. jul./dez. 2006, p. 41-62.

Jurisdição, economia e mudança social. Revista do TRF da Segunda Região, 2010, p. 143-173.

Direito, tributação e economia no Brasil: aportes da Análise Jurídica da Política Econômica. Revista da

Procuradoria-Geral da Fazenda Nacional, v.1, n.2, (jul.-dez.), 2011, p. 23-51.

Formas jurídicas e mudança social: interações entre o direito, a filosofia, a política e a economia. São Paulo: Saraiva, 2012.

Monetary Impacts and Currency Wars: A Blind Spot in the Discourse About Transnational Legal Orders? Prepared for the Law and Society Association (LSA) 2014 Annual Meeting - Minneapolis, Minnesota May 29 - June 1, 2014. Session: New Technologies: Transnational Order \& Terms of Use on Different Terms.

DAVIS, Kevin; KINGSBURY, Benedict; MERRY, Sally Engle. Introduction: Global Governance by Indicators. In: DAVIS, Kevin; FISHER, Angelina; KINGSBURY, Benedict; MERRY, Sally Engle (eds.). Governance by indicators: global power through quantification and rankings. Oxford: Oxford University Press, 2012, p. 3-28.

HALLIDAY, Terrence C.; CARRUTHERS, Bruce G. The recursivity of law: global normmaking and national lawmaking in the globalization of bankruptcy regimes. American Journal of Sociology, Vol. 112, 2007, p. 1135 1202.

HERITAGE FOUNDATION. 2015 index of economic freedom. Disponível em: <http://www.heritage.org/index> Acesso em: 19 jun. 2015.

JESSUP, Philip C. Transnational law. New Haven: Yale University Press, 1956.

LAKE, David A. Rightful rules: authority, order, and the foundations of global governance. International Studies Quarterly, vol.54, no. 1, 2010, p. 587-613.

LUZ, Lília; DURANTE, Daniel. A guerra dos pneus: a controvérsia entre Brasil e Comunidades Europeias sobre o comércio internacional de pneus usados. Desenvolvimento e meio ambiente, v. 27, no. 1, 2013, p. 37-55.

MERCOSUR. Tribunal arbitral ad hoc. Controversia entre la República Federativa del Brasil y la Republica Oriental del Uruguay sobre prohibicion de importacion de neumaticos remoldeados (remolded) procedentes de Uruguay. 9 enero de 2002.2 Disponível em: $<$ http:/ $/$ www.mercosur.int/t_generic.jsp? contentid $=440 \&$ site $=1 \&$ channel=secretaria\&seccion $=4>$. Acesso em: 08. fev. 2015.

MONTESQUIEU, Charles de Secondat, Baron de. O espírito das leis: as formas de governo, as divisões dos poderes. 2. ed. São Paulo: Saraiva, 1992.

MOTTA, Flávia Gutierrez. A cadeia de destinação dos pneus inservíveis: o papel da regulação e do desenvolvimento tecnológico. Ambiente e Sociedade, vol. 9, no. 1, 2008, p. 167-184. 
MOTTA, Sylvio; BARCHET, Gustavo. Curso de direito constitucional. 2. ed. Rio de Janeiro: Elsevier, 2009.

NOVELINO, Marcelo. Direito constitucional. 3. ed. São Paulo: Método, 2009.

OLIVEIRA, João Paulo de. Adjudicação e comércio internacional: o caso dos pneus reformados. Dissertação (Programa de Pós-Graduação em Integração da América Latina). São Paulo: Universidade de São Paulo, 2012.

SANCHEZ, Michelle Ratton; KWEITEL, Juana; BARBOSA, André Tavares; SPÉCIE, Priscila. Participação da Sociedade Civil: comércio, saúde e meio ambiente na OMC - Comunidades Europeias vs Brasil: o caso dos pneus. Cadernos Direito GV, v. 17, 2007, p. 1-78.

SHAFFER, Gregory. Transnational legal ordering and state change In: SHAFFER, Gregory (ed.) Transnational legal ordering and state change. Cambridge: Cambridge University Press, 2013a, p. 1-22.

The dimensions and determinants of state change. In: SHAFFER, Gregory (ed.) Transnational legal ordering and state change. Cambridge: Cambridge University Press, 2013b, p. 23-49.

Conclusion: the study of transnational legal ordering. In: SHAFFER, Gregory (ed.) Transnational legal ordering and state change. Cambridge: Cambridge University Press, 2013c, p. 212-6.

SOUZA, Danielle Aleixo Reis do Valle. A judicialização da política externa brasileira: a disputa na OMC sobre os pneus reformados e a arguição de descumprimento de preceito fundamental no STF. Dissertação (Departamento de Relações Internacionais). Brasília: Universidade de Brasília, 2010.

WANKE, Peter; FLEURY, Paulo Fernando. Transporte de cargas no Brasil: estudo exploratório das principais variáveis relacionadas aos diferentes modais e às suas estruturas de custos. In: DE NEGRI, João Alberto; KUBOTA; Luís Cláudio (org.). Estrutura e dinâmica do setor de serviços no Brasil. Brasília IPEA: 2006, p. 40964.

WORLD HEALTH ORGANIZATION [WHO] Global Health Observatory Data. 2015. Disponível em: <http://www.who.int/gho/publications/world_health_statistics>. Acesso em: 19 jun. 2015.

Brazil - measures affecting imports of retreaded tires. Report of the Panel. WT/DS332/R. 12 June 2007. [2007a]. Disponível em: <https://docs.wto.org>. Acesso em: 08. fev. 2015.

Brazil - measures affecting imports of retreaded tires. Report of the Appellate Body. WT/DS332/AB/R. 3 December 2007. [2007b]. Disponível em: <https://docs.wto.org>. Acesso em: 08. fev. 2015.

YALE CENTER FOR ENVIRONMENTAL LAW \& POLICY [YCELP]. Environmental performance index: global metrics for the environment. 2015. Disponível em: <http://epi.yale.edu/>. Acesso em: 19 jun. 2015.

Trabalho enviado em 12 de abril de 2016.

Aceito em 17 de julho de 2016. 